Ks. Leszek MISIARCZYK (Płock)

\title{
POCZĄTKI CHRZEŚCIJAŃSKIEJ NAUKI O WCIELENIU W PISMACH OJCÓW APOSTOLSKICH
}

Powszechnie wiadomo, że terminem Ojcowie Apostolscy określa się pisma chrześcijańskie powstałe pod koniec I i na początku II wieku, których nauczanie jest echem przepowiadania apostolskiego i cennym dopełnieniem kerygmatu spisanego w pismach kanonicznych. Znajdujemy w nich najstarsze świadectwa fragmentów wyznań wiary, formowania się teologii i moralności oraz liturgii i organizacji wspólnot chrześcijańskich. Pisma te są wyjątkowo cenne, gdyż stanowią pośredni etap między epoką Objawienia a epoką tradycji ${ }^{1}$. Należą do nich: Didache, 1 List Klemensa do Koryntian, tzw. 2 List Klemensa do Koryntian a w rzeczywistości najstarsza anonimowa homilia chrześcijańska, Listy św. Ignacego Antiocheńskiego, Męczeństwo św. Polikarpa i jego List do Filipian, fragmenty dzieł Papiasza z Hierapolis, List Barnaby i Pasterz Herma$\mathrm{sa}^{2}$. Interesująca nas tematyka wcielenia pojawia się okazjonalnie w pismach tego okresu. Próżno byłoby szukać w tekstach Ojców Apostolskich systematycznej refleksji teologicznej nad tajemnicą wcielenia. Najczęściej powraca ona w kontekście polemiki antydoketycznej w obronie realności ciała Chrystusa, albo antygnostyckiej, która podkreśla konieczność przyjęcia odkupienia „w ciele”. Nie jest żadną próbą pogłębionej systematycznej ekspozycji, lecz jedynie przedstawieniem wiary w tę tajemnicę i przestrogą przed jej zagrożeniami. Nawet jednak te nieliczne fragmenty są bezcenne przy rekonstrukcji najstarszej chrześcijańskiej nauki o wcieleniu. Pokazują bowiem stałą troskę pasterzy tamtego czasu o zachowanie całości depozytu wiary, którego elemen-

${ }^{1}$ Podstawowe informacje można znaleźć w podręcznikach do patrologii - np. J. Quasten, Patrologia, I, Casale Monferrato 1980, 44-100; G. Bosio - E. dal Covolo - M. Maritano, Introduzione ai Padri della Chiesa, I, Torino 1993, s. 33-154; H. Drobner, Patrologia, Casale Monferrato 1998, 97-114; C. Moreschini - E. Norelli, Storia della letteratura cristiana antica greca e latina, I, Brescia 1995, 161-174, 193-212; a także w opracowaniach w j. polskim - wstęp M. Starowieyskiego w: Pierwsi Świadkowie, Kraków 1998² , 5-24 oraz podręcznikowe opracowania tematyki F. Drączkowskiego, Sz. Pieszczocha, A. Żurka.

${ }^{2}$ Niektórzy dołączają do tej grupy także Ody Salomona, Ewangelię Tomasza i List do Diogneta należący już raczej do pism apologetycznych. 
tem zasadniczym była od początku wiara w przyjęcie przez Syna Bożego natury ludzkiej (ciała), z drugiej zaś strony, pozwalają nam uchwycić właśnie rozumienie tej tajemnicy w I-II wieku oraz poznać terminologię tę wiarę opisującą. W niektórych tekstach wiara w tajemnicę wcielenia jest tylko milcząco zakładana, lecz szerzej i wyraźniej nie opisywana. Tak np. w 1 Liście do Koryntian św. Klemensa znajdujemy określenia o pokornym pierwszym przyjściu Mesjasza $(16,1)$, charakterze odkupieńczym przelanej za nas Jego krwi $(7,4 ; 21,6)$ czy pochodzeniu Jezusa według ciała od Jakuba $(32,9)$, które choć oczywiście w sensie szerokim zakładają wiarę w realność ciała Chrystusa, bezpośrednio nie dotyczą jednak naszej tematyki. Podobnie tzw. 2 List do Koryntian potwierdza wiarę Kościoła zarówno w bóstwo, jak i w prawdziwe człowieczeństwo Chrystusa, czego dowodem są choćby Jego cierpienia, lecz również i tutaj nie pojawia się jeszcze sama tematyka wcielenia. W naszej rekonstrukcji nauki o wcieleniu w pismach Ojców Apostolskich sięgniemy więc tylko do tych tekstów, w których ta tematyka pojawia się wyraźnie, czyli do Listów Ignacego z Antiochii, Listu do Filipian Polikarpa ze Smyrny, Listu Branaby i Pasterza Hermasa.

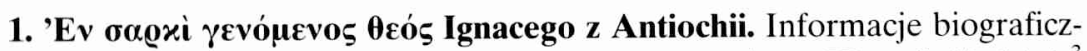
ne na temat Ignacego z Antochii czerpiemy głównie z Historii Kościoła ${ }^{3}$ Euzebiusza z Cezarei oraz z Listów napisanych przez samego biskupa w drodze na śmierć męczeńską do Rzymu. Skazany prawdopodobnie podczas lokalnego prześladowania, którego bliższe motywy nie są nam znane, odbywa wraz z innymi więźniami podróż do Rzymu zatrzymując się po drodze w Efezie, Smyrnie i Troadzie, gdzie wychodzą mu na spotkanie grupy chrześcijan wraz ze swoimi biskupami. Śmierć męczeńską ponosi w Rzymie najprawdopodobniej w 107 r. podczas igrzysk Trajana po zwycięstwie nad Dakami. W Troadzie Ignacy pisze większość swoich listów, w tym także List do Rzymian prosząc chrześcijan rzymskich, by nie starali się o jego uwolnienie. To właśnie Listy, choć wzbudzają nadal wiele kontrowersji, są dla nas jedynym źródłem informacji o teologii wcielenia biskupa Antiochii. Posiadamy trzy zbiory Listów Ignacego: siedem, trzy i trzynaście, z których badacze uznali ostatecznie zbiór siedmiu Listów za autentyczny. Niektórzy chcą podważyć autorstwo Ignacego nawet owych siedmiu Listów ze względu na obecną w nich trójstopniową hierarchię kościelną (biskupi, prezbiterzy, diakoni), gdyż ich zdaniem nie mogła ona istnieć w takiej formie już na początku II wieku.

${ }^{3}$ Por. Historia Ecclesiastica III 36. Szerzej na temat Ignacego zob. P. T. Camelot, Introduction, SCh 10 bis (Ignace d'Antioche. Polycarpe de Smyrne, Lettres, Martyre de Polycarpe, Paris $1998^{4}$ ), 9-54; wstęp W. Myszora w PSP 45 (1990); M. Starowieyski, Wołanie o jedność - Św. Ignacy Antiocheński, w: Pierwsi Świadkowie, BOK 10, Kraków 1998², 104-112; Ch. Munier, Où en est la question d'Ignace d'Antioch? Bilan d'un siècle de recherches 1870-1988, ANRW II 27.1 (1993), $359-484$. 
Możemy jednak zapytać: niby dlaczego nie mogła istnieć? Gdyż nie jest potwierdzona przez inne źródła z tego okresu? Często niestety powtarzanym błędem metodologicznym w badaniach historycznych jest próba weryfikacji za pomocą tekstów starożytnych wcześniej przyjętych założeń. Podobnie było i w tym przypadku, choć nadal zdarzają się uczeni powracający do tego typu argumentacji.

W Listach pisanych tonem bardzo osobistym Ignacy wyraża swoją żarliwą wiarą w Chrystusa usque ad mortem, troskę o inne kościoły, o jedność całego Kościoła powszechnego oraz swoją mistykę i teologię. Teologia biskupa Antiochii jest właśnie teologią mistyka i męczennika, zorientowaną na pouczanie w konkretnych kwestiach, nie zaś systematycznym, pogłębionym wywodem. Przedstawia już jednak zdecydowanie jednoznacznie kluczowe elementy wiary chrześcijańskiej: niewidzialny Bóg jest jeden (przeciw politeizmowi), objawił się On ludziom w Jezusie Chrystusie, który stał się człowiekiem i umożliwił nam dostęp do Ojca. Chrystus przyjął prawdziwe ciało, prawdziwie cierpiał i zmartwychwstał (przeciw doketom). Historyczny Jezus w swoim ciele objawił ludziom w sposób widzialny niewidzialnego Boga (przeciw gnostyzującym) ${ }^{4}$. Błędne nauki przekręcają nie tylko nauczanie Chrystusa, ale rozbijają także jedność Kościoła. Więź człowieka z naturą ludzką Chrystusa, która jest ściśle zjednoczona z Jego bóstwem, prowadzi również i ludzi do ścisłego zjednoczenia z Bogiem. Jedność zaś z Bogiem jest fundamentem jedności w Kościele, której widzialnym znakiem jest biskup, a zwłaszcza biskup Rzymu. Powszechnie znana jest teologia episkopatu Ignacego oraz teologia prymatu Kościoła w Rzymie ,przewodzącego w miłości”.

Tematem centralnym Listów Ignacego jest bez wątpienia chrystologia. Teksty traktujące o tej tematyce, pomijając oczywiście ogólne określenia o tym, że Bóg stał się dla nas widzialny (ógatóv) w Chrystusie ${ }^{5}$, możemy podzielić na dwie grupy: teksty antydoketyczne podkreślające realność wcielenia, śmierci i zmartwychwstania Chrystusa, które pojawiają się w formie antycznych wyznań wiary ${ }^{6}$ lub pojedynczych określen ${ }^{7}$ oraz teksty akcentujące jedność bóstwa i człowieczeństwa w Chrystusie ${ }^{8}$. Przedstawimy teraz krótką analizę tych tekstów rozpoczynając od pierwszej grupy. ${ }^{9}$

${ }^{4}$ Ignacy podkreśla jedność Boga oraz objawienie się Jego w Jezusie historycznym zapewne nie przeciwko konkretnym systemom gnostyckim, lecz raczej tzw. tendencjom gnostyzującym. Nie znajdujemy w Listach bezpośredniej krytyki gnostyckiego dualizmu teologicznego czy możliwości poznania Boga niewidzialnego dzięki gnosis. Fakt ten jest dodatkowym argumentem za datacją Listów na początek II wieku, por. P. T. Camelot, SCh 10bis, 20 n. 2.

5 Por. Ad Polycarpum 3,2.

${ }^{6}$ Por. Ad Trallianos 11,1; Ad Smyrnaeos 1,1-2; Ad Magnesios 11,1.

${ }^{7}$ Por. Ad Smyrnaeos 1,1; 3,3; 4,2; Ad Ephesios 20,2

${ }^{8}$ Por. Ad Ephesios 7,2; 18,2; 20,2; Ad Smyrnaeos 3,2-3; Ad Magnesios 1,2.

9 Inspiruję się tu wstępem T. Camelota, SCh 10bis, 23-30. 
Spokojny Ignacy daje się wyraźnie ponieść emocjom, gdy pisze o heretykach wypaczających naukę Pana. Nazywa ich „psami wściekłymi ${ }^{10}$, „wilkami”"11, „bestiami o kształtach ludzkich" ${ }^{12}$ czy „mistrzami błędu”"13. Chodziło prawdopodobnie o naukę tzw. judaizujących, rozpowszechnianą w Syrii i Azji Mniejszej, jak to potwierdzają listy do Smyrneńczyków i Magnezjan ${ }^{14}$. Zachęcali oni nie tylko do zachowywania przepisów Prawa Mojżeszowego ${ }^{15}$, ale przede wszystkim, i to było dla Ignacego zasadniczym zagrożeniem, negowali realność ciała i męki Jezusa utrzymując, iż posiadał On tylko pozorne ciało i pozornie cierpiał. Cierpienie i śmierć na krzyżu były dla wyznawców tej nauki skandalem, co potwierdzałoby, iż chodziło prawdopodobnie o judaizantes nie akceptujących Mesjasza cierpiącego (Gal 5,11). Negowali oni realność ciała Chrystusa bynajmniej nie ze względu na jako taką pogardę do ciała, ale z motywów soteriologicznych, odrzucając właśnie realność Jego cierpień. Ma rację Camelot zauważając, iż nie byli to prawdopodobnie jeszcze gnostycy w sensie znanych nam późniejszych systemów, lecz raczej spekulacje gnostyckie w szerszym znaczeniu. Określa on ich mianem doketów judaizujących, znanych już wcześniej środowisku Janowemu (1 J 1,1-3; 4,1-3). Gnostycy, podobnie jak owi dokeci judaizujący, również relatywizowali odkupienie ,, ciele" Chrystusa, ale czynili to z innych powodów. Z Listów Ignacego wynikałoby natomiast, iż jego polemika jest skierowana raczej przeciwko właśnie doketom negującym najpierw realność cierpień Chrystusa, a potem w konsekwencji realność Jego ciała. Ignacy odpowiada na takie poglądy przytaczając reguły wiary swoich czasów używane prawdopodobnie podczas celebracji liturgii chrzcielnej i Eucharystii. W Liście do Tralian czytamy:

„Bądźcie więc głusi, kiedy mówią wam o czymś innym niż o Jezusie Chrystusie, z rodu Dawida, Synu Maryi, który naprawdę się narodził, który jadł i pił, naprawdę był prześladowany za Poncjusza Piłata, naprawdę został ukrzyżowany i umarł, i oglądały Go niebo i ziemia, i otchłań. On też naprawdę powstał z martwych". ${ }^{16}$

Są tutaj już zawarte zasadnicze elementy wiary chrześcijańskiej: wcielenie, narodzenie, życie ludzkie, śmierć i zmartwychwstanie Chrystusa. Tajemnica wcielenia jest wyrażona za pomocą wprowadzanych jak refren określeń

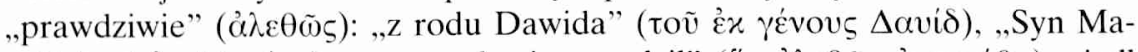

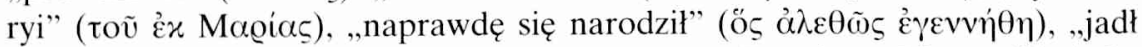

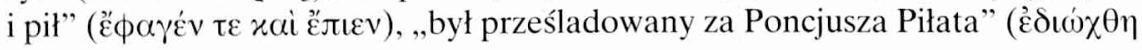

\footnotetext{
10 Por. Ad Ephesios 7,1.

11 Por. Ad Philadelphienses 2,2.

12 Por. Ad Smyrnaeos 4,1.

13 Por. Ad Polycarpum 3,1.

14 Por. Ad Simyrnaeos 1,6; Ad Magnesios 10,11.

15 Por. Ad Magnesios 9,1; Ad Smyrnaeos 6,1.

16 Ad Trallianos 9,1-2. SCh 10bis, 100, tłum. A. Swiderkówna, BOK 10, 126.
} 


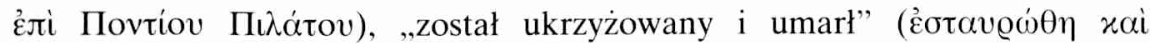
$\alpha \dot{\alpha} \dot{\theta} \theta v \varepsilon v)$. Kluczowym argumentem za realnością wcielenia jest tutaj oczywiście realność śmierci Chrystusa, rozbudowana o wątki jedzenia i picia oraz historyczną wzmiankę o Piłacie. Samo zaś wcielenie jest wyrażone za pomocą terminologii biblijnej: pochodzenie z rodu Dawida nawiązuje do Rz 1,3 (

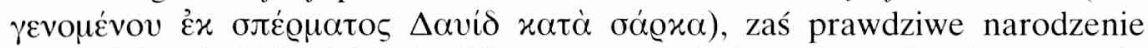
z Maryi do Mt 1,18n; Łk 2,1n. Warto zauważyć, iż w tej regule wiary pojawia się już imię Maryi, Matki Jezusa, a czasownik opisujący narodzenie $\dot{\varepsilon} \gamma \varepsilon v v \eta \dot{\theta} \eta \eta$ od $\gamma \varepsilon v v \alpha \dot{\omega} \omega$ występuje w Mt 1,20 i Łk 1,35 w zapowiedzi narodzenia Mesjasza przez anioła. Podobnie jak w przypadku Apologii Arystydesa, którą zobaczymy dalej, również i tutaj widzimy wyraźnie, iż do wyznań wiary w I wieku włączano słowa anioła traktując je także jako „objawione”. List do Smyrneńczyków trochę inaczej rozkłada akcenty:

„Co dotyczy Pana naszego, który będąc naprawdę według ciała z rodu Dawida, jest Synem Boży według woli i potęgi Boga, naprawdę się urodził z Dziewicy, został ochrzczony przez Janaa za Poncjusza Piłata i tertrarchy Heroda naprawdę został przybity za nas w ciele". ${ }^{17}$

Łatwo zauważyć elementy nowe: chrzest Jana, udział Heroda w ukrzyżowaniu i podkreślenie natury boskiej Chrystusa. Jeśli zaś chodzi o wcielenie, to powtarza się „prawdziwie” oraz pochodzenie według ciała z rodu Dawida

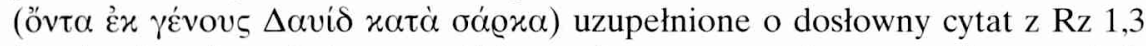
( $x \alpha \tau \dot{\alpha} \sigma \alpha ́ \varrho x \alpha)$, co było oczywiście zamierzonym wyakcentowaniem mesjańskiej tożsamości Jezusa; podkreślone jest również, bez jakiegokolwiek komen-

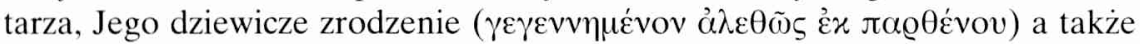

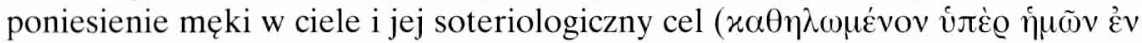
бa@xi). List do Magnezjan natomiast zachęca do wiary „w narodzenie

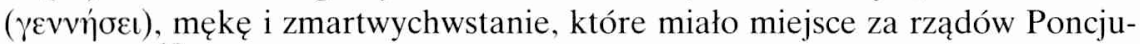
sza Piłata"18. Reguły te są bez wątpienia śladami najstarszych pozabiblijnych wyznań wiary, jakie posiadamy. Ignacy powraca jeszcze do tematyki realności ciała Chrystusa w pojedynczych zdaniach przy okazji polemiki z poglądami głoszącymi pozorność cierpienia, męki i zmartwychwstania Chrystusa w Liście do Smyrneńczyków i Efezjan ${ }^{19}$, gdy nawiązuje znowu do pochodzenia ,z rodu

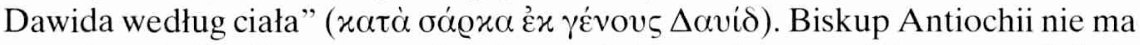
wątpliwości, że Chrystus posiadał prawdziwe ciało, prawdziwie narodził się z Dziewicy Maryi z rodu Dawida, prawdziwie cierpiał na krzyżu, umarł i zmartwychwstał za panowania Poncjusza Piłata i Heroda, a nawet po zmartwychwstaniu, jak czytamy w Liście do Smyrneńczyków: ,jadł i pił z uczniami jak istota

\footnotetext{
17 Ad Magnesios 11,1, SCh 10bis, 132, BOK 10, 136.

18 Ad Magnesios 11,1, SCh 10bis, 90, BOK 10, 122.

19 Por. Ad Smyrnaeos 4,2; Ad Ephesios 20,2.
} 


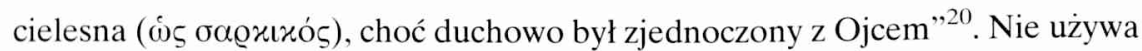
nigdy terminu $\sigma \tilde{\omega} \mu \alpha$, lecz $\sigma \alpha \dot{\varrho} \xi$, w znaczeniu jednak nie tyle kruchości natury ludzkiej, jak choćby św. Paweł, ale raczej w sensie rzeczywistej natury ludzkiej polemizując w ten sposób z doketami ${ }^{21}$.

Drugim elementem, który bardzo wyraźnie akcentuje w swojej chrystologii św. Ignacy, jest jedność natury boskiej i ludzkiej w Chrystusie. Dzięki swojej naturze ludzkiej ( $\sigma \alpha ́ \varrho \xi)$ Syn Boży żyje jak każdy człowiek, natomiast dzięki swej naturze boskiej pozostaje ciagle zjednoczony z Ojcem ${ }^{22}$. Biskup Antiochii podobnie jak Hermas w Pasterzu, używa terminu $\pi v \varepsilon \tilde{v} \mu \alpha$ na określenie natury boskiej Chrystusa, a wcielenie opisuje również według schematu $\tau v \varepsilon \tilde{u} \mu \alpha-\sigma \alpha ́ \varrho \xi$. Chrystus jest jednocześnie człowiekiem narodzonym z Maryi i Synem Bożym. I choć Ignacy nie używa jeszcze terminologii teologicznej wypracowanej później, to jednak w inny sposób wyraża wiarę w ścisły związek dwóch natur Chrystusa w jedności Jego osoby, właśnie przeciwko doketom. Właściwe rozumienie tajemnicy wcielenia zakłada bowiem również wiarę w bóstwo Chrystusa. Jeśli nie jest On Synem Bożym, który wcielił się, a jedynie zwykłym człowiekiem, to nie może być mowy o prawdziwym wcieleniu. Gdy człowiek staje się człowiekiem, nie mamy do czynienie z wcieleniem. Ignacy nie godzi się jednak także na proponowane przez doketów przyjęcie pozornego wcielenia rzekomo w celu uratowania bóstwa Chrystusa. Przyjęcie rzeczywistego bóstwa i człowieczeństwa w Chrystusie jest warunkiem koniecznym właściwego ujęcia Jego prawdziwej tożsamości. Klasycznym tekstem biskupa Antiochii, który przedstawia tę tematykę jest List do Efezjan:

„Jeden jest lekarz, cielesny i duchowy, zrodzony i niezrodzony, przychodzący w ciele Bóg, w śmierci życie prawdziwe, zrodzony z Maryi i zrodzony z Boga, najpierw podległy cierpieniu, a teraz mu już nie podlegający, Jezus Chrystus nasz Pan". 23

Słusznie Camelot podkreśla, że dla Ignacego ciało i duch w tym tekście nie są elementami natury ludzkiej, ale oznaczają naturę ludzką i boską Chrystu$\mathrm{sa}^{24}$. Zrozumiałe jest określenie $\gamma \varepsilon v v \eta \tau$ tó jako narodzenie z Maryi, ale zapewne budzi zdziwienie termin $\alpha \gamma \varepsilon ́ v v \varepsilon \tau o \varsigma$ użyty na opisanie natury boskiej Chrystusa. Musimy jednak pamiętać, iż termin àyévvetos, przez wielu Ojców przednicejskich był odnoszony do istoty Boga, a nie do jednej z Osób boskich. $\mathrm{Z}$ punktu widzenia Credo Nicejskiego określenie to mogłoby być rozumiane

${ }^{20}$ Ad Smyrnaeos 3,3, SCh 10bis, 134, BOK 10, 136.

21 Por. Camelot, Introduction, SCh 10bis, 26.

22 Por. Ad Smyrnaeos 3,2-3; Ad Magnesios 1,2.

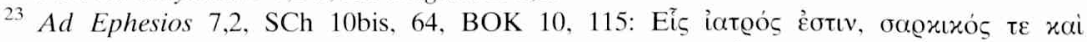

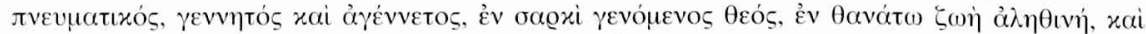

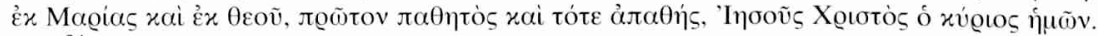

${ }^{24}$ Por. Introduction, SCh 10bis, 26. 
na sposób heretycki, ale dla Ignacego oznacza po prostu transcendencję Boga, a konkretniej - naturę boską Chrystusa. Wreszcie ostatni, kluczowy dla nas

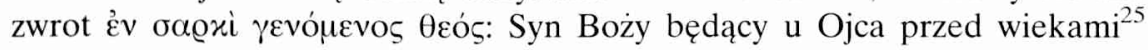
ukazał się na końcu czasów, stając się „Bogiem w ciele”. Truizmem będzie uwaga, iż nie można tego zwrotu rozumieć „Bogiem stał się w ciele”, ale odwrotnie, jest „Bogiem przychodzącym w ciele”, jak to znakomicie przetłumaczyła pani prof. A. Świderkówna.

\section{Antydoketyczna chrystologia w Liście do Filipian Polikarpa ze Smyrny.} Choć Ireneusz z Lyonu wspomina o kilku listach Polikarpa, do naszych czasów przetrwał niestety jedynie List do Filipian. ${ }^{26}$ Autentyczność Listu jest wystarczająco dobrze potwierdzona właśnie przez Ireneusza ${ }^{27}$, jak i Euzebiusza z Cezarei ${ }^{28}$. Zdecydowanie więcej problemów stwarza natomiast sam tekst. Okazją do napisania listu była najprawdopodobniej prośba Ignacego, by przekazać jeden z jego listów braciom z Macedonii, która zbiegła się zapewne w czasie z prośbą samych Filipian do Polikarpa o przesłanie im wszystkich możliwych pism Ignacego. Wtedy najprawdopodobniej Polikarp wysłał pierwszą grupę listów Ignacego (bez Listu do Rzymian), dołączając do nich swój List do Filipian. Bardzo szybko jednak badacze zauważyli pewne sprzeczności w samym tekście. Otóż, w r. 9 znajdujemy wzmiankę na temat Ignacego i jego towarzyszy, którzy „są teraz na należnym im miejscu przy Panu, gdyż z Nim także razem cierpieli" ${ }^{29}$. Natomiast w r. 13 sam Polikarp zdaje się dopytywać Filipian o los Ignacego: „A dajcie nam znać, jeśli dowiedzieliście się czegoś pewnego o samym Ignacym i jego towarzyszach"30. Te sprzeczności stały się dla niektórych uczonych podstawą do zanegowania autentyczności samego listu. Słusznie jednak podkreśla Camelot, iż tradycja tekstualna oraz świadectwo Euzebiusza przypisują autorstwo listu jednoznacznie właśnie Polikarpowi. ${ }^{31}$.

Tematyka Listu jest zasadniczo pastoralna. Jeśli chodzi o chrystologię, to w tekście biskupa Smyrny znajdujemy tradycyjne stwierdzenia teologiczne. Chrystus jest najwyższym kapłanem i Synem Bożym $(12,2)$, z drugiej zaś strony, w kontekście polemiki z doketami, autor broni realności Jego ciała. Problem wcielenia pojawia się w Liście do Filipian zaledwie w kilku miejscach.

25 Por. Ad Magnesios 6,1.

26 Obok powszechnie znanych wątków biograficznych por. T. Camelot, Introduction, SCh 10bis, s.159-163; M. Starowieyski, Mądry i gorliwy pasterz - św. Polikarp ze Smyrny, BOK 10, 149-155.

${ }^{27}$ Por. Adversus haereses III 3,4.

${ }^{28}$ Por. Historia Ecclesiastica III 36, 13-15.

${ }^{29}$ Epistola ad Philippenses 9,2, SCh 10bis, 188, thum. A. Świderkówna, BOK 10, 159.

30 Tamze, 13,2, Funk I s. 312, BOK 10, 161.

${ }^{31}$ Por. Introducion, SCh 10bis, 164-167; William R. Schoedel, Polycarp of Smyrna and Ignatius of Antioch, ANRW II 27.1 (1993), 272-358 (bibliografia). 
W r. 8,1-2 Polikarp nawiązując wyraźnie do $1 \mathrm{P} 2,24$ by pokazać, że Chrystus ,w swoim ciele poniósł nasze grzechy na drzewo" i „wycierpiał wszystko"32. Biskup Smyrny używa tu tzw. argumentu z rzeczywistego cierpienia Chrystusa przemawiającego za prawdziwością Jego ciała. Praktycznie jedynym tekstem, w którym autor mówi szerzej o wcieleniu, jest rozdział 7:

\begin{abstract}
„Każdy bowiem, kto nie uznaje, że Jezus Chrystus przyszedł w ciele, jest antychrystem, kto nie uznaje świadectwa krzyża, ten jest z diabła, a kto według swoich własnych pragnień zniekształca powiedzenia Pana, mówiąc, że nie ma ani zmartwychwstania, ani sądu, taki czlowiek jest pierworodnym Szatana". ${ }^{33}$
\end{abstract}

W tym fragmencie łatwo zauważyć polemikę z różnymi fałszywymi poglądami: negacją przyjścia Chrystusa w ciele, negacją realności Jego męki i śmierci na krzyżu, negacją zmartwychwstania i sądu nad wszystkimi ludźmi. Widać więc tutaj wyraźne odniesienie do nauk doketyzmu. Warto zauważyć, że negacja charakteru odkupieńczego śmierci na krzyżu, zmartwychwstania i sądu była konsekwencją bardziej fundamentalnej negacji rzeczywistego człowieczeństwa Chrystusa. Polikarp argumentuje więc odwrotnie niż Ignacy. Nazywając antychrystem każdego, kto neguje realność ciała Chrystusa, przytacza praktycznie myśl z 1 Listu św. Jana 4,2-3 dokonując oczywiście pewnych zmian i syntetyzując. W 1 J 4,2-3 autor przestrzega by nie dowierzać każdemu duchowi, lecz badać je, czy są z Boga, i jako zasadnicze kryterium rozróżniania podaje właśnie uznawanie przyjścia w ciele Jezusa. Duch ( $\pi v \varepsilon \tilde{v} \mu \alpha)$, który wyznaje przyjście Jezusa w ciele, jest z Boga, natomiast negujący to, nie jest z Boga, lecz z antychrysta ${ }^{34}$. Nie chodzi tutaj oczywiście o Ducha Świętego, ale o duchy (myśli) inspirujące chrześcijańskich nauczycieli. Testem jest publiczne wyznanie przyjścia Chrystusa w ciele, co mogłoby wskazywać na wiarę we wcielenie jako kluczowy element ,,apostolskiego wyznania wiary”. Punktem centralnym kontrowersji nie było więc pytanie o człowieczeństwo Jezusa, ale o związek Jego „bycia w ciele" ze zbawieniem ${ }^{35}$. Polikarp pozostaje wierny tej myślii. ${ }^{36}$ Nie mówi już o duchach, ale o osobach fałszujących naukę Pana dotyczącą odkupienia, a są to ci, którzy odrzucają Jego przyjście w ciele. Błędna teologia wcielenia doketów prowadziła logicznie do błędnej soteriologii. To właśnie

32 Por. Epistola ad Philippenses 8,1-2, SCh 10bis, 186, BOK 10, 159.

33 Tamze, 7,1, SCh 10bis, 186, BOK 10, 159

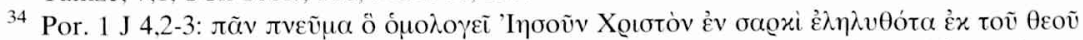

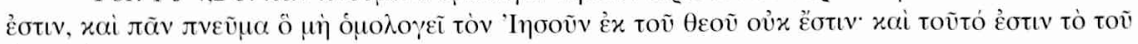
àvтıxoíotov

${ }^{35}$ Szerzej zob. P. Perkins, The Johannine Epistles, Dublin 1979, 49-52; tenze, The Johannine Epistles, w: R. Brown - J. A. Fitzmyer - R. E. Murphy, The New Jerome Biblical Commentary, London 1992, 986-993, tutaj s. 992.

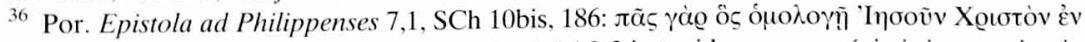

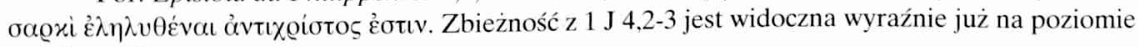
terminologii. 
było punktem centralnym argumentacji zarówno autora 1 J 4,2-3 jak i Polikarpa w Liście do Filipian 7,1.

Podkreślmy tytułem zakończenia, iż biskup Smyrny przytacza i eksplikuje tradycyjne nauczanie Nowego Testamentu, zwłaszcza 1 J 4,2-3, broniąc zdecydowanie realnego ciała Chrystusa jako fundamentu prawdziwej soteriologii. Ze względu na kontekst antydoketyczny była to siłą rzeczy chrystologia Syn Boży-sarx.

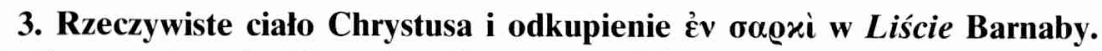
Współczesna krytyka literacka nie ma zasadniczo wątpliwości, iż tzw. List Barnaby nie jest w rzeczywistości ani typowym starożytnym listem, ani jego autorem nie jest Apostoł Barnaba, towarzysz św. Pawła ${ }^{37}$. Brak początkowego i końcowego pozdrowienia oraz forma zwracania się do adresatów wskazują raczej na charakter katechetyczny pisma. Znaczenie przypisywane tekstowi w starożytności chrześcijańskiej, łączone zapewne z autorstwem Apostoła Barnaby, musiało być wielkie, skoro jeszcze wielki Orygenes zalicza ten list do grona Listów Apostolskich, zaś słynny Kodeks Synaicki umieszcza go pośród ksiąg Nowego Testamentu. Świadectwa zewnętrzne i krytyka wewnętrzna pozwalają określić datę powstania pisma na lata trzydzieste II wieku. Trudniej jest natomiast określić dokładniej autora i miejsce powstania tekstu. Autorem jest prawdopodobnie jakiś Barnaba, różny jednak od Apostoła Barnaby, towarzysza Św. Pawła. Wiele wskazuje na to, iż był on albo chrześcijanienem pochodzenia żydowskiego albo etnochrześcijanienem znającym bardzo dobrze zwyczaje i teologią judaizmu. Adresatami Listu byli najprawdopodobniej judaizujący etnochrześcijanie, gdyż to właśnie zagrożenia płynące ze strony judaizmu niejako zmusiły autora do interwencji piórem. Na treść pisma składają się dwie części: pouczenia teologiczne (r. 2,4-17) i moralne (18-20). Druga część (r. 1820), to przytoczony z drobnymi zmianami żydowski podręcznik etyki „Dwie drogi" znany wcześniej z Didache.

Tematem centralnym Listu Barnaby jest bez wątpienia chrystologia, która pojawia się tylko w części pierwszej naszego dzieła. Niewiele jednak znajdziemy odniesień w samym tekście na temat życia, nauczania, czynów, zwłaszcza cudów Jezusa historycznego. Dla autora Chrystus jest Synem Bożym (5,9; 12,8$10 ; 15,5)$ i Panem $(5,1.5 ; 7,2 ; 12,11 ; 14,4-5)$, istniał przed wszelkim stworzeniem i uczestniczył w stwarzaniu świata $(5,5.10)$ oraz był natchnieniem dla proroków $(5,6)$. Zrealizował On zbawczy plan Boga odnawiając całe stworzenie $(6,11)$, a przygotowując Ojcu nowy lud chrześcijański dał początek królestwu, które zostanie ostatecznie dopełnione wraz z Jego paruzją $(7,11 ; 8,6)$. W tym celu

37 Oprócz opracowań podręcznikowych na temat Listu Ps-Barnaby por. P. Prigent, Introduction, w: Épître de Barnabé, trad. R. A. Kraft, SCh 172, Paris 1971, 9-70; M. Starowieyski, Chrześcijanstwo i judaizm - List Barnaby, BOK 10, 174-178. 
konieczne było przyjęcie przez Niego ciała i poniesienie męki na krzyżu. Warto

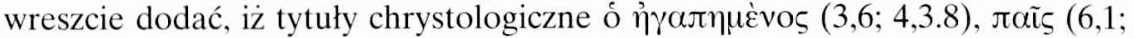
9,2), $\lambda i \theta$ os (6,2-4), pojawiające się w Liście są charakterystyczne dla antycznych chrystologii, powstałych w środowiskach syro-palestyńskich.

To właśnie w kontekście chrystologicznym, jak należało przypuszczać, pisze Barnaba o tajemnicy wcielenia. Broni zdecydowanie przeciwko doketom i gnostykom zarówno soteriologicznej motywacji, jak również realności wcielenia i męki Chrystusa. Tematyka wcielenia i cierpienia łączą się zresztą ze sobą bardzo ściśle. Barnaba, podobnie jak inni pisarze chrześcijańscy tego okresu, z prawdziwości cierpień Jezusa wnioskuje o prawdziwości Jego wcielenia i odwrotnie. Tekstów mówiących o wcieleniu jest w Liście niestety niewiele i są to raczej stwierdzenia szerzej nie komentowane. I tak, pierwsza grupa tekstów mówi ogólnie o cierpieniu Chrystusa w ciele. W 5,5 autor zastanawia się, jak to jest możliwie, by władca świata cierpiał z ręki człowieka: „Pan zgodził się cierpieć za nas, chociaż jest władcą wszechświata całego". ${ }^{38}$ Jeszcze wyraźniej ekspiacyjny charakter cierpień Syna Bożego pro nobis jest podkreślony w typologicznej interpretacji kozła ofiarnego (Kpł 16): „otóż jeśli Syn Boży, choć jest Panem, cierpiał, aby Jego rany przyniosły nam życie, wierzymy zatem, że Syn Boży nie mógł cierpieć z innego powodu niż dla nas" ${ }^{\text {"39 }}$ i wywyższonego węża ${ }^{40}$. Barnaba rozwija w tych fragmentach praktycznie nauczanie Św. Pawła: w celu zwyciężenia śmierci oraz by wypełnić proroctwa zapowiadające to zwycięstwo, Chrystus musiał przyjąć śmiertelne ciało ludzkie ${ }^{41}$. Wcielenie prezentowane jest tu w funkcji soteriologicznej czy wręcz jako swego rodzaju pierwszy etap dzieła odkupienia. W ten sposób Barnaba dołącza do tych pisarzy wczesnochrześcijańskich, którzy starali się udzielać odpowiedzi na pytanie cur Deus homo. Wyraźnym dopełnieniem wyżej przytaczanych tekstów jest wypowiedź:

„Dlatego bowiem zgodzi się Pan wydać swoje ciało na zniszczenie, aby nas oczyścić przez odpuszczenie grzechów, którego dokonuje pokropienie krwią Jego" ${ }^{42}$

Tutaj autor nawiązuje nie tylko ogólnie do cierpień Chrystusa, ale precyzuje, iż to właśnie Jego ciało stało się „narzędziem” zbawienia człowieka poprzez odpuszczenie grzechów. Wyczuwa się tutaj polemikę z gnostykami: Chrystus dokonał dzieła odkupienia w swoim ciele i nie może się ono realizować poprzez gnosis.

38 Epistola Barnabae 5,5, SCh 172, 108, tłum. A. Świderkówna, BOK 10, 183.

39 Tamże, 7,2, SCh 172, 128, BOK 10, 186.

${ }^{40}$ Por. tamże, 12,5, SCh 172, 168, BOK 10, 192: „Innym znów razem, kiedy Izraelowi groziła zagłada, uczynił Mojżesz coś, co było zapowiedzią Jezusa, to jest, że ma cierpieć i że On właśnie będzie źródłem życia, choć wyda się, że znalazł śmierć na znaku".

${ }^{41}$ Por. P. Prigent, Introduction, SCh 172, s. 108 n. 1.

42 Epistola Barnabae 5, 1, SCh 172, 104, BOK 10, 183. 
Do drugiej grupy należą teksty traktujące już bezpośrednio o tematyce wcielenia. Barnaba używa w nich dwóch określeń na opisanie tej tajemnicy wiary: „objawił się w ciele” i ,przyszedł w ciele”. W 5,6 objawienie się w ciele jest nadal przedstawiane jako warunek odkupienia:

„On zaś zgodził się cierpieć, gdyż mając zwyciężyć śmierć i dowieść swego zmartwychwstania musiał objawić się w ciele" ${ }^{43}$

Zgoda Chrystusa na cierpienie oraz realność Jego śmierci i zmartwychwstania domaga się realnego wcielenia. Podkreślanie realizmu męki i wcielenia Chrystusa to wyraźna polemika z doketyzmem, natomiast akcentowanie odkupienia, dokonanego w ciele, skierowane jest przeciw gnostykom. Tematyka objawienia się Syna Bożego w ciele i Jego męki również w ciele powraca jeszcze

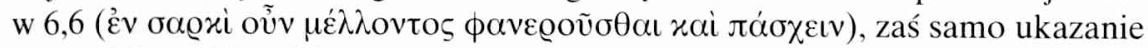
się w ciele w 6,9 , gdzie autor polemizując z gnozą pisze o prawdziwej wiedzy, którą jest pokładanie nadziei w mającym się objawić właśnie w ciele Jezusa

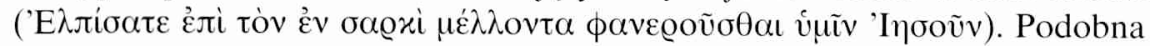

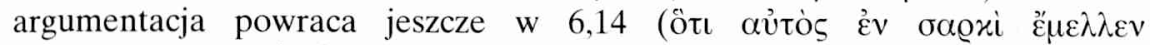

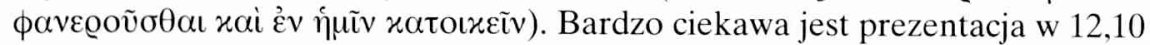

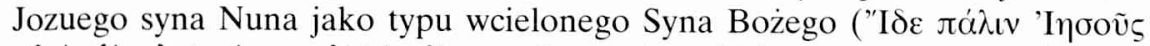

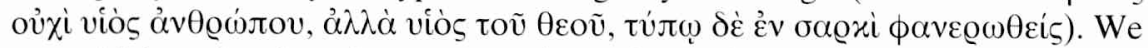
wszystkich tych tekstach powtarza się praktycznie ten sam zwrot w różnych

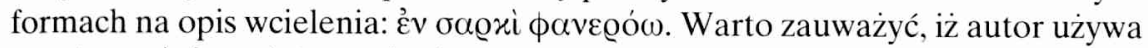

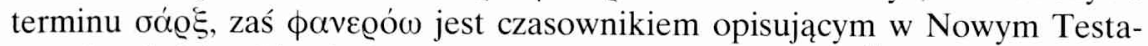
mencie właśnie objawianie dzieł Jezusa albo Ojca ludziom ${ }^{44}$.

Kolejny zwrot na opisanie wiary we wcielenie Syna Bożego w Liście Barnaby to „przyjść w ciele”. Pojawia się on jednak tylko dwa razy obok. Według autora, gdyby ,nie przyszedł w ciele, jakże ludzie mogliby Go oglądać i pozostać przy życiu" ${ }^{45}$ oraz „Syn Boży po to przyszedł w ciele, aby dopełnić miary grzechu tych, którzy aż do śmierci prześladowali proroków" ${ }^{46}$. W obydwu wersetach występuje ten sam zwrot grecki દ’v $\sigma \alpha \varrho x i$ iे $\lambda \theta \varepsilon v$. Werset pierwszy podkreśla, iż jednym z motywów wcielenia było ułatwienie ludziom prawdziwej kontemplacji Boga, która przedtem była niemożliwa ze względu na słabość natury ludzkiej. Argument ten, zdaniem Prigenta, pojawia się również wśród gnostyków jako przekonanie, że wcielenie było swego rodzaju dostosowaniem się Boga do zdolności człowieka ${ }^{47}$. Natura ludzka Chrystusa, jego

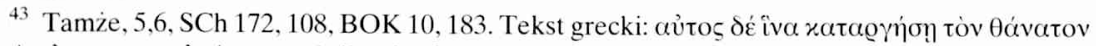

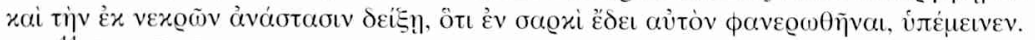

${ }^{44}$ Por. R. Popowski, Wielki stownik grecko-polski Nowego Testamentu, Warszawa 1997, s. 635; zob. także W. F. Moulton - A. S. Geden - H. K. Moulton, A Concordance to the Greek Testament, Edinburgh 1986, s. 984.

${ }^{45}$ Epistola Barnabae 5,10, SCh 172, 110, BOK 10, 183.

46 Tamże, 5, 11, SCh 172, 112, BOK 10, 183. 
ciało, staje się pośrednikiem w kontakcie z Bogiem, i jest to, jak wiemy, przekonanie całej późniejszej mistyki katolickiej. Termin oá@g trzeba więc w konsekwencji rozumieć tutaj chyba raczej jako naturę ludzką, niż jako zwyczajne ciało. Natomiast werset drugi podaje nam jeszcze inny motyw wcielenia: Syn Boży przyjął ciało, aby dopełnić miary grzechów Żydów, którzy wcześniej prześladowali proroków Bożych. Mamy tutaj wyraźne nawiązanie do polemiki antyżydowskiej, obecnej w tekstach Nowym Testamencie, jak Mt 23,31-32; Dz 7,52; 1 Tes 2,15.

Podsumowując możemy powiedzieć, iż Barnaba przedstawia swoją teologię wcielenia wyraźnie w kontekście polemiki antydoketycznej i antygnostyckiej. Przeciw doketom akcentuje realność przyjęcia ciała przez Chrystusa, wynikającą z realności Jego cierpień, męki i zmartwychwstania, natomiast w polemice antygnostyckiej autor podkreśla, iż prawdziwe odkupienie dokonało się દ̉v

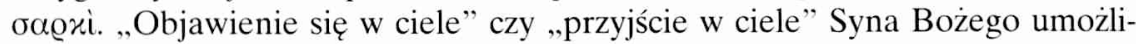
wia ludziom kontemplację prawdziwego oblicza Boga.

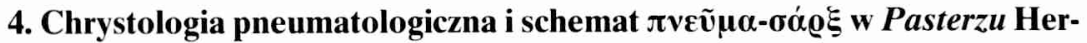
masa. Hermas, jak potwierdza Kanon Muratoriego, przebywał w Rzymie za pontyfikatu papieża Piusa I (140-150) i wtedy napisał swoje dzieło Pasterz. Wątpliwości badaczy wzbudzają nie tylko niektóre elementy biograficzne z życia autora, jak np. wzmianki o żonie i synach apostatach, ale także jego autorstwo całego pisma. Nie wchodząc w owe skomplikowane i szczegółowe kwestie możemy za większością badaczy stwierdzić, iż zawarta w nim stosunkowo archaiczna teologia, wspominane prześladowania, zapewne z czasów cesarza Trajana i Antonina Piusa, wzrost wspólnoty chrześcijańskiej w Rzymie oraz rygoryzm praktyki pokutnej, czynią prawdopodobnym powstanie tego pisma w połowie II wieku ${ }^{48}$.

Pismo należy do gatunku literackiego apokaliptyki, który przy pomocy symboli i wizji interpretuje obecną historię oraz zapowiada ostateczne zwycięstwo Boga. Sam zastosowany gatunek literacki dopuszcza możliwość wielu interpretacji niejednoznacznych stwierdzeń, symboli, wizji czy wręcz często sprzecznych wyrażeń. Szczególna ostrożność jest wskazana zwłaszcza w przypadku stwierdzeń teologicznych obecnych w Pasterzu. Apokaliptyczny tekst chrześcijański z II wieku to przysłowiowa interpretacyjna ,mieszanka wybuchowa". Pismo jest chaotyczne i nie najwyższych lotów nie tylko od strony literackiej, ale także teologicznej. Nie spodziewajmy się znaleźć w nim wyrafinowanej refleksji. Składają się na nie: pięć widzeń, dwanaście przykazań

${ }^{47}$ Por. Introduction, SCh 172, s. 111 n. 4.

48 Szerzej na ten temat por. R. Jolly, Introduction, w: Hermas, Le Pasteur, SCh 53bis, 2 ed., Paris 1998, 11-74 (też bibiografia); M. Starowieyski, W kręgu chrześcijańskiego wizjonerstwa Hermas, w: Pierwsi świadkowie, BOK 10, Kraków 1998, 205-210; F. Szulc, Spór o „Pasterza” Hermasa, VoxP 2 (1982) z. 3, 340-355. 
i dziesięć przypowieści (podobieństw). Wiodącym wątkiem Pasterza jest kwestia pokuty chrześcijańskiej. Autor podkreśla, iż oprócz pierwszego zgładzenia grzechów, jakim jest przyjęcie chrztu, istnieje również możliwość drugiej pokuty i drugiego przebaczenia grzechów po chrzcie, jednak tylko jeden raz ${ }^{49}$. Tematem zaś centralnym pisma, jak słusznie zauważa ks. F. Szulc, jest eklezjologia, czyli rozumienie natury Kościoła i jego władza nad grzechami, z którym łączą się ściśle chrystologia, pneumatologia, angelologia i antropologia ${ }^{50}$. Konieczność wielkiej ostrożności w interpretacji naszego tekstu wymagana jest zwłaszcza właśnie w chrystologii. Niektóre bowiem sformułowania autora rozumiane dosłownie prowadzą często do konkluzji zupełnie absurdalnych. Zasadniczo przyjmuje się jako podstawę do zrozumienia chrystologii Pasterza Przypowieści 2, 5 i 9. Musimy jednak ciągle pamiętać, że podstawowym znaczeniem Przypowieści w Pasterzu jest raczej sens parenetyczny, nie zaś dogmatyczny. Rozumiane dosłownie Przypowieści 2 i 5 prowadzą np. do stwierdzenia, że Jezus odkupił ludzi tylko z własnej inicjatywy, niezależnie od woli Boga, lub też że został adoptowany jako Syn dzięki modlitwom ludzi ${ }^{51}$.

Nie można analizować nauki o wcieleniu Hermasa nie umieszczając jej w kontekście chrystologii Pasterza, która jest skomplikowana i wieloaspektowa. Ks. F. Szulc słusznie wyodrębnił, rozumiejąc oczywiście chrystologię $\mathrm{w}$ sensie szerokim, kilka wiodących koncepcji w chrystologii Hermasowej. ${ }^{52}$ Należą do nich: chrystologia imienia, chrystologia angelomorficzna, chrystologia pneumatologiczna oraz tytuły chrystologiczne o charakterze eklezjo-centrycznym. Pierwsza inspirowała się judaistyczną teologią Imienia Boga, natomiast druga związana była ze swoistą chrystologizacją postaci anioła Michała. Obydwie rozwijały się w środowisku judeochrześcijańskim. Warto zauważyć, iż Hermas nie wykorzystuje praktycznie zupełnie Logoschrystologie, znanej przecież chrześcijańskiej refleksji teologicznej II wieku. Najważniejsza z perspektywy naszych obecnych analiz jest oczywiście chrystologia pneumatologiczna, gdyż to właśnie w jej kontekście pojawia się tematyka wcielenia. Hermas nie pisze o wcieleniu ani według „klasycznego” schematu Logos-sarx, ani według innych schematów możliwych do wyprowadzenia z jego chrystologii, a więc np. onoma-sarx czy angelos-sarx, a jedynie według bardzo oryginalnego i jednocześnie skomplikowanego modelu $\pi v \varepsilon \tilde{u} \mu \alpha$ - $\sigma \alpha \dot{\varrho} \xi$. W celu lepszego zrozumienia

${ }^{49}$ Szerzej na temat pokuty zob. np. S. Czerwik, Zarys dziejów pokutnej praktyki Kościoła, w: A. Skowronek (red.), Sakrament pokuty, Katowice 1980, 127-175; A. Młotek, Pokuta i pojednanie w Kościele pierwotnym, „Colloqium Salutis” 17 (1985) 167-184; J. Janicki, Pokuta w nauczaniu i praktyce Kościoła dwóch pierwszych wieków, „Folia Historica Cracoviensia” 3(1996) $287-304$.

${ }^{50}$ Por. F. Szulc, Chrystologia „Pasterza” Hermasa jako problem badawczy, VoxP 6 (1986) z. 10, 117-135. Artykuł ten jest niewątpliwie jednym z najbardziej wartościowych wkładów polskojęzycznych do badań nad Pasterzem.

51 Por. Jolly, Introduction, SCh 53bis, 31.

52 Por. Chrystologia „Pasterza” Hermasa jako problem badawczy, art. cyt. 124-125. 
nauki o wcieleniu w Pasterzu należy umieścić ją w szerszym kontekście chrystologii pneumatologicznej, która już sama w sobie jest sporna i bardzo trudna do interpretacji. W przeszłości interpretując Przypowieść 5 popełniano, zdaniem F. Szulca, podstawowy błąd metodologiczny, starając się za wszelką cenę uzgodnić chrystologię tam przedstawioną z chrystologią Nowego Testamentu albo też z chrystologią późniejszą. Niestety, nie przynosiło to oczekiwanych rezultatów, a nawet zaciemniało jeszcze bardziej i tak już niejasny obraz. Wiemy, że nie można nakładać na II wiek późniejszej precyzacji chrystologicznej, ale jak rozumieć, pytamy, chrystologię Pasterza „sprzeczną” z chrystologią nowotestamentalną. Chodzi tylko o heretycki regres teologiczny czy też raczej o właściwe zrozumienie języka autora? W Przypowieści $5 \mathrm{w}$ oparciu o liczne teksty biblijne o tematyce winnicy (Iz 5,1n.; Ir 2,21; Mt 21,33n.) Hermas tworzy swoją opowieść wyjaśniając potem jej znaczenie:

„Ziemia to świat nasz; właściciel ziemi to Ten, kto wszystko stworzyl, uporządko-
wał i obdarzył mocą, Syn jest Duchem Świętym, a niewolnik Synem Bożym”.

Jak zauważyło wielu badaczy, dla Hermasa Synem Bożym jest Duch Święty. Ściśle jednak mówiąc nie wynika to wcale tak jednoznacznie z wyżej przytoczonego tekstu. Syn jest Duchem Świętym, ale tekst nie mówi wcale, że chodzi o Syna Bożego. Ta identyfikacja jest jednak jeszcze bardziej wyraźna w Przypowieści 9, gdzie Anioł Pokuty przychodzi kolejny raz i chce ukazać Hermasowi wszystko to, co mu ukazał Duch Święty, który przemawiał do niego pod postacią Kościoła: „Duch ten bowiem jest Synem Bożym” (દ̇xeĩvo

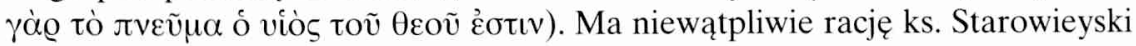
stwierdzając, że wypowiedzi Hermasa „na tematy dogmatyczne wprawiają w popłoch historyków teologii i patrologów”, ale nie mniej słusznie podkreśla ks. F. Szulc, iż ten popłoch jest spowodowany błędną próbą przykładania ortodoksyjnej chrystologii przed- i po-Hermasowej do chrystologii naszego autora. Oczywiście, z perspektywy teologii późniejszej chrystologia Hermasa będzie pneumatologiczna i adopcjonistyczna, a jego teologia trynitarna, właściwie binarną. I choć prawdą jest, iż nie znajdujemy późniejszych tekstów patrystycznych, które nawiązywałyby w jakikolwiek sposób do chrystologii Pasterza, niemniej jednak sam fakt przechowywania tego pisma i otaczania go szacunkiem w Kościele pierwszych wieków musi dawać do myślenia. Nawet jeśli to czyniono, tylko ze względu na doktrynę pokutną. O ile jednak łatwo jest zakwestionować z punktu widzenia metodologicznego próbę porównywania chrystologii Hermasa z chrystologią późniejszą, o tyle jej odniesienie do chrystologii nowotestamentalnej stwarza zdecydowanie większe problemy.

53 Pastor. Similitudo V 58, 2, SCh 53bis, 234-236, thum. A. Świderkówna, BOK 10, 255. Tekst

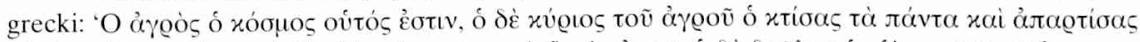

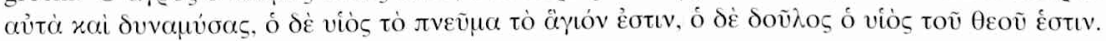


Nie do końca można się chyba zgodzić z F. Szulcem, traktującym trochę na równi studium porównawcze chrystologii Hermasa z chrystologią późniejszą i wcześniejszą. Oczywiście w próbie opisania i zrozumienia tej chrystologii musimy analizować tekst Pasterza taki, jaki jest, bez wstępnych założeń, gdyż zawsze grozi nam trochę automatyczna tendencja do uzgadniania $\mathrm{z}$ tymi właśnie założeniami wniosków naszych analiz. Gdybyśmy jednak poprzestali tylko na tym, byłoby to zatrzymanie się w połowie drogi. Do ostatecznej oceny potrzebujemy przecież jakiejś miary, jakiegoś kryterium. W przypadku chrystologii, takim kryterium jest chrystologia objawiona w Nowym Testamencie. Jeśli błędne metodologicznie będzie porównywanie chrystologii Hermasa $\mathrm{z}$ chrystologią Nowego Testamentu, to co w takim razie należy przyjąć jako punkt odniesienia w chrystologii w ogóle? Takim punktem nie może być tylko chrystologia judeochrześcijańska, gdyż ona sama dla siebie domaga się punktu odniesienia w nauce objawionej.

Zacznijmy od bardzo prostego stwierdzenia: brak wyraźnego rozróżnienia pomiędzy Synem i Duchem Świętym nie jest tylko specjalnością Hermasa, lecz pojawia się również u innych pisarzy chrześcijańskich tego okresu, jak choćby u Justyna czy Tacjana ${ }^{54}$. Sam jednak brak jasności, zarówno w rozumieniu Ducha Świętego, jak i Jego relacji do Syna nie przesądza jeszcze o heterodoksyjności poglądów autorów II wieku, gdyż często miarą ortodoksyjności w tym względzie jest pneumatologia i chrystologia późniejsza. Bardziej problematyczna jest interpretacja Przypowieści 5, z której, zdaniem niektórych badaczy, wynika, jakoby Bóg posiadał dwóch Synów: Ducha Świętego jako Syna w sensie właściwym, oraz Jezusa Chrystusa w sensie adopcyjnym ${ }^{55}$. Na to niejako nakładają się rozbieżności pomiędzy uczonymi na temat rozumienia owej adopcji Chrystusa: jedni widzą w Pasterzu chrystologię wyraźnie adopcjonistyczną, inni tylko archaiczną, lecz ortodoksyjną. By sprawy jeszcze bardziej skomplikować dodajmy, iż według naszego autora, to właśnie Duch Święty wcielił się, jak czytamy w V Przypowieści:

„Duchowi Świętemu, który jest od wieków i wszystko stworzył, zgotował Bóg mieszkanie w ciele, które sobie wybrał. Tak więc ciało, w którym zamieszkał, służyło dobrze Duchowi krocząc zawsze drogami świętości i czystości, niczym Ducha nie kalając". 56

${ }^{54}$ Pneumatologia II wieku i relacje między Synem a Duchem Świętym zasługują oczywiście na odrębne studium.

55 Syntezę tych poglądów przytaczam za: F. Szulc, Chrystologia „Pasterza” Hermasa jako problem badawczy, VoxP 6 (1986) z. 10, 129 n.

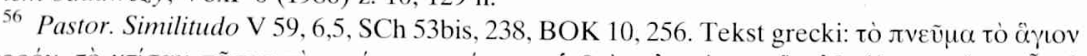

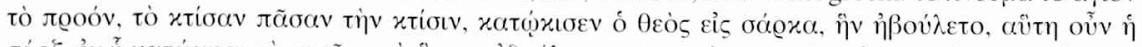

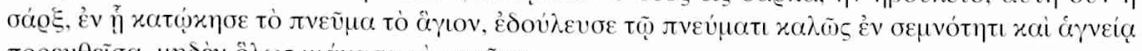

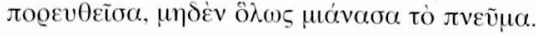


Odnosi się wrażenie, iż według Hermasa to właśnie Duch Święty wcielił się w Jezusa. Jak rozumieć te teksty? Niektórzy badacze, by obronić ortodoksyjność tych poglądów, proponują rozumieć przez Ducha Świętego boską naturę Chrystusa, podkreślając, iż właśnie w r. 89,2 jest wyraźnie podkreślone istnienie Syna Bożego przed wszelkim stworzeniem. Problem tylko w tym, że dla Hermasa Synem Bożym wydaje się być właśnie Duch Święty. Ks. Szulc słusznie proponuje szukać, nie tylko dla chrystologii pneumatologicznej Hermasa, ale także dla modelu $\pi v \varepsilon \tilde{v} \mu \alpha-\sigma \alpha \dot{\varrho} \xi$, prezentacji wcielenia w teologii starotestamentalnej i późnojudaistycznej. Jego zdaniem, fundamentem biblijnym takiej refleksji były teksty Izajasza (11,1-9; 42,1-9) oraz judaistyczna idea Mesjasza obdarzonego Duchem Jahwe. Dodajmy jeszcze, że sam Chrystus rozpoczyna swoją misję w Nazarecie od lektury Izajasza $(61,1 \mathrm{n} ; 58,6)$ i stwierdzenia, iż w Nim wypełniają się te słowa $(\mathrm{k} 4,16-30)$. Nawet jeśli nie są to ipsissimia verba Jesu, lecz stwierdzenia redakcyjne, to i tak potwierdzają one przekona-

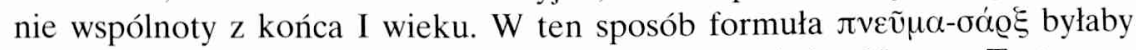
najstarszym schematem chrystologicznym, obecnym już w Nowym Testamencie (Rz 1,3n.; 1 P 3,18; 1 Tm 3,16) i innych pismach wczesnochrześcijańskich, jak choćby analizowane wcześniej Listy Ignacego. Z taką właśnie teologią wcielenia, łączącą Ducha Jahwe z Mesjaszem, Sługą Jahwe, mamy do czynienia w Pasterzu. Według F. Szulca Hermas zaczerpnął najprawdopodobniej tę ideę od środowisk judeochrześcijan aplikując ją do interpretacji pneumatologicznej chrystologicznego tytułu Nowego Testamentu, jakim było określenie „Syn Boży" "57. Zakłada on oczywiście, że chrystologia pneumatologiczna Pasterza jest pneumatologiczną „przeróbką" chrystologicznego tytułu nowotestamentalnego „Syn Boży”. Nie jest to jednak wcale tak do końca oczywiste ani przekonujące i domaga się głębszego uzasadnienia. Nie można bowiem wykluczyć, że Hermas przekazuje nam tutaj tradycję bardzo antyczną, może nawet wcześniejszą niż ostateczna redakcja Nowego Testamentu, a więc w konsekwencji także wcześniejszą niż chrystologiczne rozumienie tytułu „Syn Boży” w Nowym Testamencie. A jeśli tak, to wtedy trzeba by odwrócić całe rozumowanie, tzn. pneumatologiczna chrystologia Hermasa nie byłaby reinterpretacją nowotestamentalnego tytułu „Syn Boży”, ale odwrotnie, byłaby ona najbardziej archaiczną próbą opisania tajemnicy Chrystusa w środowisku judeochrześcijan. Tego typu tradycja mogła istnieć w formie spisanej bądź jeszcze ustnej być może już w latach 40-70 I wieku. Następnie później zostałaby pominięta lub zastąpiona przez Ewangelistów tytułem chrystologicznym „Syn Boży”, gdyż używanie terminu ,pneuma” na określenie boskiej natury Chrystusa i opisywanie tajemnicy wcielenia w schemacie $\pi v \varepsilon \tilde{v} \mu \alpha-\sigma \alpha ́ \varrho \xi$ mogło łatwo prowadzić do błędnego utożsamiania Syna z Duchem Świętym. Najdziwniejsze, że takie właśnie utożsamienie jest obecne w samym Pasterzu. Jeśli rozumowa-

57 Por. Chrystologia „Pasterza” Hermasa jako problem badawczy, VoxP 6 (1986) z. 10, 131. 
nie wyżej przedstawione ma jakikolwiek sens, to należałoby przypuszczać, że fragmenty Pasterza dotyczące chrystologii są bardzo starymi tradycjami, znanymi być może już w połowie I wieku, lecz przechowywane w środowisku judeochrześcijan, nie znających ewangelicznej korekty tego typu chrystologii na chrystologię „Syna Bożego”, centralną przecież choćby w Ewangelii Marka. Tradycje te zostałyby włączone do Pasterza traktującego zasadniczo przecież o pokucie. Takie rozumowanie zdają się potwierdzać słowa Jezusa w synagodze w Nazarecie (Łk 4,16-30), jeśli są to rzeczywiście ipsissima verba Jesu i tekst św. Pawła (Rz 1,3n.) ${ }^{58}$. Jeśli bowiem rację ma F. Szulc, to niejasna pozostaje kwestia zasadnicza: dlaczego w II wieku lub później nie skorygowano chrystologii Hermasa, zwłaszcza jego identyfikacji Syna Bożego z Duchem Świętym w oparciu o Nowy Testament? Są to oczywiście tylko pewne intuicje, które wymagają jeszcze dokładniejszych analiz, na które w obecnym artykule nie ma niestety miejsca. Słuszna intuicja F. Szulca o judaistycznych korzeniach chrys-

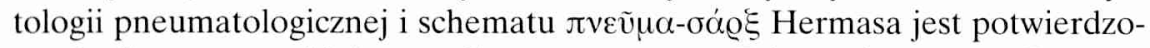
na choćby przez pobieżną analizę semantyczną. Jak pamiętamy, w Pasterzu

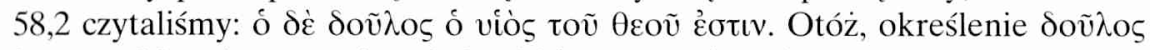
jest greckim tłumaczeniem hebrajskiego עבד (ebed) - sługa, termin, który pojawia się w słynnych tekstach o Słudze Cierpiącym (Iz 42,1; 49,3.5.6; 50,10;

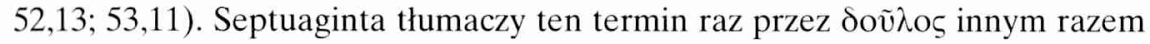
przez лaĩs. Wiemy, że w judaizmie rabinicznym, choć oczywiście ciągle pozostaje trudna kwestia datacji tych tradycji, owe pieśni o Słudze Cierpiącym odnoszono właśnie do Mesjasza, zaś termin đaĩ był we wczesnym chrześcijaństwie tytułem chrystologicznym.

Choć konieczne są dokładniejsze badania nad chrystologią Hermasa, to już na powyższym przykładzie można by się pokusić o przypuszczenie, iż w Paste$r z u$ mamy ślady archaicznej chrystologii judeochrześcijańskiej. Być może takie właśnie cechy nosiła antyczna, jeszcze przedewangeliczna (przedmarkowa) tradycja o Synu Bożym, która wraz ze schematem teologii wcielenia $\pi v \varepsilon \tilde{v} \mu \alpha-$ $\sigma \alpha \dot{\varrho} \xi$ była znana już w latach 40/50-70 I wieku. Są to oczywiście tylko pewne intuicje, które domagają się dalszych, dokładniejszych analiz. Niezbędne wydaje się w tym kontekście studium na temat chrystologii pneumatologicznej Nowego Testamentu i jej relacji do innych tytułów chrystologicznych. Zakończę jednak trochę może przewrotnym pytaniem: być może chrystologia Hermasa dałaby się najzwyczajniej w świecie wyjaśnić dzięki studium porównawczemu z chrystologią Ignacego, który, jak wiemy, używa właśnie schematu

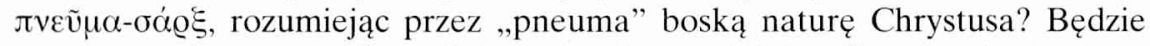
to co prawda powrót do podejmowanych wcześniej prób rozumienia przez „pneuma” transcendencji czy „natury boskiej” Chrystusa, jak w Listach Ignacego, ale nie widzę powodów, dla których trzeba by taki kierunek badań

58 Por. A. Grillmeier, Gesù Cristo nella fede della Chiesa, I, Brescia 1982, s. 118n. 
odrzucić, nawet jeśli w przeszłości nie przyniósł oczekiwanych rezultatów. Listy Ignacego Antiocheńskiego potwierdzają bowiem, że nie tylko była możliwa, ale również de facto funkcjonowala w chrześcijaństwie pierwotnym „ortodok-

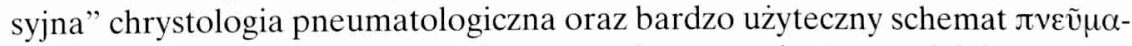

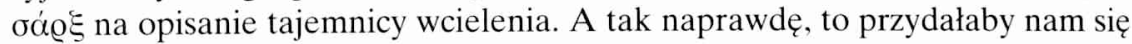
dobra monografia na temat chrystologii pneumatologicznej w Nowym Testamencie i pismach Ojców Kościoła.

W podsumowaniu rozważań na temat wcielenia u Ojców Apostolskich trzeba zauważyć, że Ignacy Antiocheński w polemice z judaizującymi doketami bronił realizmu wcielenia podkreślając, że Chrystus posiadał prawdziwe ciało, prawdziwie narodził się z Dziewicy Maryi z rodu Dawida, prawdziwie cierpiał na krzyżu, umarł i zmartwychwstał za panowania Poncjusza Piłata

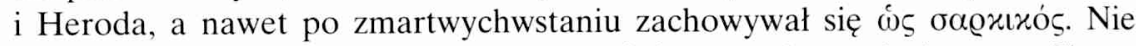
używał nigdy terminu $\sigma \tilde{o} \mu \alpha$, zawsze zaś $\sigma \alpha \dot{\alpha} \xi$, w sensie przyjęcia przez Chrystusa rzeczywistej natury ludzkiej. Przeciwko doketom i spekulacjom gnostyckim Ignacy podkreślał, że Chrystus jest Synem Bożym i człowiekiem jedno-

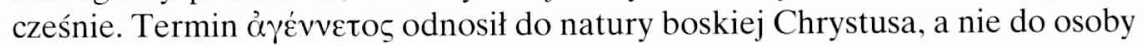
Boga jak teologowie ponicejscy. Tajemnicę wcielenia opisywał za pomocą

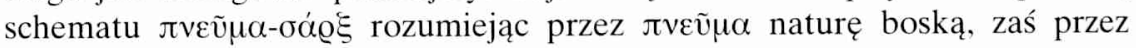

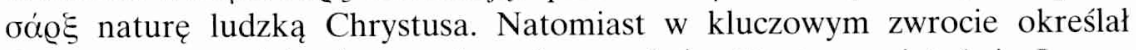

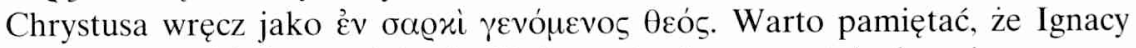
daje nam przykład „ortodoksyjnej” chrystologii pneumatologicznej.

Polikarp ze Smyrny z kolei bronił zdecydowanie realności ciała Chrystusa jako fundamentu prawdziwej soteriologii, argumentuje odwrotnie niż św. Ignacy. Ze względu na kontekst antydoketyczny przedstawiał tajemnicę wcielenia według schematu Syn Boży-sarx. Teologia wcielenia w Liście Barnaby wyrasta również wyraźnie z kontekstu polemiki antydoketycznej i antygnostyckiej. Akcentuje realność ciała Chrystusa przeciw doketom, która jego zdaniem, podobnie jak w listach Ignacego, wynika z realności Jego cierpień, męki i zmartwychwstania. Natomiast w polemice antygnostyckiej podkreślał, iż nie istnieje żadne odkupienie za pośrednictwem gnosis, lecz jedynym prawdziwym odkupieniem jest to, którego dokonał Chrystus w swoim ciele. Za jeden z celów wcielenia Syna Bożego uważał autor umożliwienie ludziom kontemplację Boga w ,formie cielesnej”.

W kontekście wreszcie tzw. chrystologii pneumatologicznej Hermas używał, podobnie jak Ignacy, schematu $\pi v \varepsilon \tilde{v} \mu \alpha-\sigma \alpha \varrho \xi \xi$ na opisanie tajemnicy wcielenia. Zarówno sama chrystologia, jak i przedstawiony schemat mogą być najbardziej archaicznymi formami prezentacji Chrystusa i wcielenia, istniejącymi w środowisku judeochrześcijan być może już w drugiej połowie I wieku. 
Warto na zakończenie podkreślić, iż wszyscy autorzy oprócz polemiki z poglądami błędnymi na temat wcielenia, głównie doketyzmem i spekulacjami gnostyckimi, przedstawiają także pozytywny wykład rozumienia w Kościele starożytnym tej tajemnicy wiary. Czynią to często, jak choćby w przypadku Ignacego, przytaczając starożytną regułę wiary.

\section{TEOLOGIA DELL'INCARNAZIONE NEI SCRITTI DEI PADRI APOSTOLICI}

(Sommario)

S. Ignazio di Antiochia polemizzando con i doceti giudaizzanti difende energicamente la realtà dell'incarnazione sottolineando che Cristo ha assunto una vera e non fittizzia carne umana, è nato veramente dalla Vergine Maria dalla stirpe di Davide, veramente patì sulla croce, veramente è morto e risorto nei tempi di Ponzio Pilato e di Erode. Perfino dopo la sua risurrezione si è comportato Ignazio prende come punto di partenza delle le sue riflesioni sull'incarnazione di Cristo la realtà delle sue sofferenze e della morte sulla croce negati dalle correnti del pensiero che con difficoltà accettavano il Messia sofferente. Vescovo di Antiochia non adopera mai il termine $\sigma \tilde{\omega} \mu \alpha$ per descrivere la vera carne di Cristo, ma sempre oর́@g intendendo con quest'ultimo la vera natura umana di Cristo. Egli difende quindi anche contro i sudetti doceti giudaizzanti e le speculazioni gnostiche la realtà sia della vera natura umana che quella divina in Cristo. Di conseguenza il termine à $\gamma \varepsilon \dot{v} v \varepsilon \tau o \varsigma$ lo riferisce non alla persona di Dio Padre come sarà fatto più tardi, ma alla natura di Cristo. Il mistero dell'incarnazione Ignazio lo descrive secondo lo schema $\pi v \varepsilon \tilde{v} \mu \alpha-\sigma \alpha \dot{\varrho} \xi$ intendendo con $\pi v \varepsilon \tilde{v} \mu \alpha$ la natura divina e con $\sigma \alpha \dot{\xi} \xi$ la natura umana di

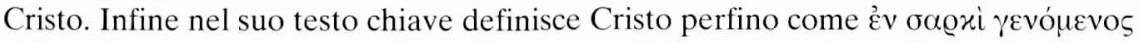

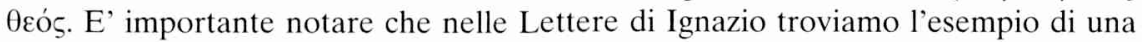
cristologia pneumatica conforme ai dati della rivelazione, quindi „ortodossa”.

Policarpo di Smirne, anche lui nella sua Lettera ai Filippesi difende la realtà dell'incarnazione. La sua argomentazione però è diversa da quella di Ignazio. Secondo vescovo di Antiocha Cristo ha assunto una carne vera perchè veramente ha sofferto, invece per Policarpo al contrario, l'incarnazione è il fondamento della redenzione. Sarà superfluo ricordare che si tratta ovviamente soltanto di ordine argomentativo e non effettivo. Anche per Ignazio l'incarnazione è fondamento della soteriologia. Policarpo presenta l'incarnazione di Cristo secondo lo schema Figlio di Dio-sarx.

La teologia dell'incarnazione nella Lettera di Barnaba si iscrive anch'essa nel contesto della polemica antidoceta ed antignostica. La sua argomentazione antidoceta assomoglia quella di Ignazio, cioè, dalla realtà della passione e risurrezione di 
Cristo egli deduce la realtà della carne di Cristo. Invece nella polemica antignostica (ovviamente non contro i sistemi gnostici, ma contro le speculazioni gnostiche) autore rifiuta la possibilità di una redenzione disincarnata attraverso gnosis insistendo sul fatto che unica e vera redenzione è quella operata da Cristo nella sua carne. Come uno dei scopi dell'incarnazione del Figlio di Dio Barnaba mette in rilievo quello di dare agli uomini la possibilità di contemplare Dio in "forma carnale".

Erma nel Pastore descrive l'incarnazione, come Ignazio, secondo lo schema

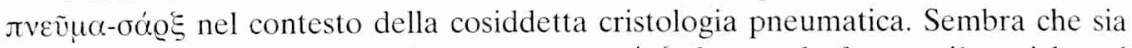
la cristologia stessa che lo schema $\pi v \varepsilon \tilde{u} \mu \alpha-\sigma \alpha ́ \varrho \xi$ fossero le forme più antiche ed arcaiche della cristologia e dell'incarnazione nate negli ambienti giudeocristiani forse già nella seconda metà del I secolo. Infine bisogna sottolineare che tutti gli autori, salvo forse Erma, oltre alla polemica contro le false presentazioni dell'incarnazione come docetismo o speculazioni gnostiche, presentano anche l'esposizione positiva di questa verità di fede cristiana. Lo fanno, come nal caso di s. Ignazio, riportando antica regula fidei. 